\title{
WOJEWÓDZKA KOMISJA DS. ORZEKANIA O ZDARZENIACH MEDYCZNYCH A WOJEWODA - ROLE I ZAKRESY ODPOWIEDZIALNOŚCI W ZAKRESIE PRZETWARZANIA DANYCH OSOBOWYCH
}

\begin{abstract}
Abstrakt: Artykuł porusza problem relacji między komisją do spraw orzekania o zdarzeniu medycznym a wojewodą w zakresie przetwarzania danych w celu ustalenia zdarzenia medycznego. Problematyka jest istotna z punktu widzenia określenia zadań, ról i odpowiedzialności tych podmiotów za proces przetwarzania danych osobowych. Istotne $z$ praktycznego punktu widzenia jest wskazanie, czy między tymi organami zachodzi relacja odrębnych administratorów, czy współadministrowania danymi osobowymi.
\end{abstract}

Słowa kluczowe: wojewódzka komisja do spraw orzekania o zdarzeniach medycznych, wojewoda, dane osobowe, dane medyczne, przetwarzanie danych osobowych, współadministrowanie

\section{UWAGI WSTĘPNE}

W toku udzielania świadczeń medycznych może dojść do nieprawidłowości będących efektem działań albo zaniechań. Ich skutkiem mogą być negatywne konsekwencje dla pacjenta lub jego rodziny: uszczerbek na zdrowiu albo śmierć. Wówczas pacjent albo jego spadkobiercy mogą dochodzić swoich praw przed sądem cywilnym albo wojewódzką komisją do spraw orzekania o zdarzeniach medycznych. Wojewódzkie komisje są podmiotami, których celem postępowania jest ustalenie, czy zdarzenie, którego następstwem była szkoda majątkowa lub niemajątkowa, stanowiło zdarzenie medyczne. Przedmiotem postępowania przed komisją jest dochodzenie roszczeń odszkodowawczych z tytułu zdarzeń medycznych.

Sama komisja jest organem quasi-sądowym. W założenia jej funkcjonowania wpisane jest, że między jej członkami nie ma konfliktu, nie zaś ustrojowa niezależność i odrębność. Komisja jest zatem instytucją samodzielną i niezależną pod względem organizacyjnym i funkcjonalnym zarówno od struktury wymiaru sądownictwa, jak i od struktury systemu administracji publicznej. Wykonywanie za- 
dań komisji wojewódzkiej nie stanowi wykonywania władzy publicznej. Postępowanie przed wojewódzką komisją jest pozasądowym postępowaniem cywilnym, alternatywnym wobec długotrwałych procesów sądowych sposobem dochodzenia roszczeń w sprawach medycznych ${ }^{1}$.

\section{POSTĘPOWANIE PRZED WOJEWÓDZKĄ KOMISJĄ DO SPRAW ORZEKANIA O ZDARZENIACH MEDYCZNYCH}

Komisje funkcjonujące od dnia 1 stycznia 2012 roku na podstawie ustawy o prawach pacjenta i Rzeczniku Praw Pacjenta ${ }^{2}$, powołane zostały w każdym województwie, a ich siedzibą jest siedziba właściwego urzędu wojewódzkiego. W skład wojewódzkiej komisji wchodzi szesnastu członków. Ośmiu z nich ma wykonywać zawód medyczny przez okres co najmniej pięciu lat albo mieć stopień naukowy doktora w dziedzinie nauk medycznych. Pozostali winni być zatrudnieni przez okres co najmniej pięciu lat na stanowiskach związanych ze stosowaniem lub tworzeniem prawa albo posiadać stopień naukowy doktora w dziedzinie nauk prawnych. Czternastu członków komisji powołuje wojewoda, po jednym minister właściwy do spraw zdrowia i Rzecznik Praw Pacjenta.

Kadencja wojewódzkiej komisji wynosi sześć lat. Członek komisji może być odwołany przed jej upływem przez organ, który go powołał w następujących przypadkach:

1. złożenia rezygnacji ze stanowiska,

2. choroby trwale uniemożliwiającej wykonywanie powierzonych zadań,

3. zaistnienia okoliczności określonych $\mathrm{w}$ art. $67 \mathrm{~g}$ ust. 1 u.p.p.,

4. niezłożenia oświadczenia, o którym mowa $\mathrm{w}$ art. $67 \mathrm{~g}$ ust. 4 ,

5. zaistnienia okoliczności określonych art. 67e ust. 4 (prawomocne skazanie, środek karny, kara w postępowaniu dyscyplinarnym).

Pracami wojewódzkiej komisji kieruje przewodniczący wybrany w tajnym głosowaniu, spośród jej członków na pierwszym posiedzeniu. Musi on uzyskać większość głosów, przy obecności co najmniej trzech czwartych jej członków.

${ }^{1}$ Charakter prawny wojewódzkich komisji do spraw orzekania o zdarzeniach medycznych był wielokrotnie przedmiotem analizy w literaturze, zob. A. Jarocha, Postępowanie przed wojewódzka komisja do spraw orzekania o zdarzeniach medycznych, „Studia Prawa Publicznego” 2013, nr 1, s. 46 n.; U. Drozdowska, O przedmiocie i charakterze prawnym spraw rozstrzyganych przez Wojewódzkie Komisje do Spraw Orzekania o Zdarzeniach Medycznych, „Forum Prawnicze” 2019, nr 5, s. 80-84; E. Bagińska, Działalność wojewódzkich komisji do spraw orzekania o zdarzeniach medycznych a wykonywanie władzy publicznej, [w:] Kompensacja szkód wyniktych ze zdarzeń medycznych. Problematyka cywilnoprawna i ubezpieczeniowa, red. E. Kowalewski, Torun 2011, s. 151; oraz D. Karkowska, Ustawa o prawach pacjenta i Rzeczniku Praw Pacjenta. Komentarz, Warszawa 2016, s. 496.

2 Ustawa z dnia 6 listopada 2008 roku o prawach pacjenta i Rzeczniku Praw Pacjenta, tekst jedn. Dz.U. 2020 r. poz. 849. 
Komisja, zgodnie $\mathrm{z}$ art. $67 \mathrm{f}$ u.p.p., działa na podstawie uchwalonego przez siebie regulaminu i orzeka w składzie czteroosobowym. Termin pierwszego posiedzenia składu orzekającego oraz kierującego jego pracami wyznacza przewodniczący komisji. Przed powołaniem do składu orzekającego, członkowie wojewódzkiej komisji składają oświadczenia o braku konfliktu interesów. Wszystkie osoby w niej zasiadające, zobowiązane są do zachowania w tajemnicy uzyskanych w toku postępowania przed komisją informacji dotyczących pacjenta. Ustanie członkostwa nie zwalnia ich z jej dotrzymania.

Główną przesłanką wszczęcia postępowania przed komisją jest prawdopodobieństwo wystąpienia tak zwanego zdarzenia medycznego. Zgodnie z art. 67a ust. 1 u.p.p. zdarzenie medyczne oznacza zakażenie pacjenta biologicznym czynnikiem chorobotwórczym, uszkodzenie ciała lub rozstrój zdrowia pacjenta albo śmierć pacjenta będące następstwem niezgodnych z aktualną wiedzą medyczną:

1. diagnozy, jeżeli spowodowała ona niewłaściwe leczenie albo opóźniła właściwe leczenie, przyczyniając się do rozwoju choroby,

2. leczenia, w tym wykonania zabiegu operacyjnego,

3. zastosowania produktu leczniczego lub wyrobu medycznego.

Skutek w postaci zakażenia pacjenta biologicznym czynnikiem chorobotwórczym, uszkodzenia ciała, rozstroju tudzież śmierci, musi pozostawać w adekwatnym związku przyczynowym (w rozumieniu art. $361 \S 1$ k.c.) między szkodą na osobie (w postaci zakażenia, uszkodzenia ciała, rozstroju zdrowia lub śmierci chorego), a niezgodnymi z lege artis medicinae czynnościami z zakresu diagnozy, terapii lub zastosowania produktu (wyrobu) medycznego ${ }^{3}$. Przepisy ustawy o prawach pacjenta, dotyczące zdarzeń medycznych, mają bowiem zastosowanie tylko do zdarzeń medycznych, będących następstwem udzielania świadczeń zdrowotnych w szpitalu, w rozumieniu przepisów ustawy o działalności leczniczej ${ }^{4}$. Warunkiem koniecznym uznania zdarzenia za zdarzenie medyczne jest udzielenie świadczeń medycznych niezgodnie z aktualną wiedzą medyczną 5 .

Postępowanie przed komisją jest dwuetapowe. Celem pierwszego etapu jest rozpoznanie wniosku o ustalenie zdarzenia medycznego. Jeżeli wojewódzka komisja uwzględni wniosek, a zatem ustali istnienie zdarzenia medycznego, następuje drugi etap postępowania. To tak zwana procedura ugodowo-mediacyjna między podmiotem składającym wniosek a ubezpieczycielem albo podmiotem

${ }^{3}$ E. Bagińska, K. Krupa-Lipińska, Zdarzenie medyczne a problem przyczynowości, [w:] Kompensacja szkód wyniktych ze zdarzeń medycznych. Problematyka cywilnoprawna i ubezpieczeniowa, red. E. Kowalewski, Toruń 2011, s. 255-256.

${ }^{4}$ Ustawa z dnia 15 kwietnia 2011 roku o działalności leczniczej, tekst jedn. Dz.U. z 2020 r. poz. 295. Zgodnie z art. 2 ust. 1 pkt 9, szpital to przedsiębiorstwo podmiotu leczniczego, w którym podmiot ten wykonuje działalność leczniczą w rodzaju świadczenia szpitalnego.

5 M. Paszkowska, Rozstrzyganie roszczeń pacjenta w trybie administracyjnym, „Przegląd Prawa Publicznego" 2013, nr 7-8, s. 54. 
leczniczym prowadzącym szpital, zmierzająca do ustalenia wysokości odszkodowania lub zadośćuczynienia (por. art. 67k u.p.p.) ${ }^{6}$.

Postępowanie przed komisją wszczynane jest, zgodnie $\mathrm{z}$ art. $67 \mathrm{~b}$ ust. 1 u.p.p., na wniosek pacjenta lub jego przedstawiciela ustawowego, a w razie śmierci pacjenta - jego spadkobiercy. W świetle art. 67 u.p.p. wniosek powinien zawierać:

- dane pacjenta (imię i nazwisko, datę urodzenia, PESEL), a także imię i nazwisko przedstawiciela ustawowego lub spadkobierców (a także wskazanie, który ze spadkobierców reprezentuje pozostałych w postępowaniu),

— adres do doręczeń,

- dane podmiotu leczniczego prowadzącego szpital,

- uzasadnienie wniosku zawierające uprawdopodobnienie zdarzenia oraz szkody majątkowej lub niemajątkowej,

- wskazanie, czy przedmiotem wniosku jest zakażenie, uszkodzenie ciała, rozstrój zdrowia albo śmierć pacjenta,

— propozycję wysokości odszkodowania i zadośćuczynienia (nie wyższą niż 100 tys. zł lub w przypadku śmierci 300 tys. zł).

Do wniosku należy dołączyć:

- dowody uprawdopodabniające okoliczności wskazane we wniosku,

— potwierdzenie uiszczenia wymaganej opłaty oraz, jeżeli wniosek wnoszą spadkobiercy pacjenta, postanowienie o stwierdzeniu nabycia spadku i pełnomocnictwo do reprezentowania pozostałych spadkobierców, w przypadku złożenia wniosku przez co najmniej jednego z nich.

Opłata (w wysokości 200 zł) podlega zaliczeniu na poczet kosztów postępowania przed wojewódzką komisją do spraw orzekania o zdarzeniach medycznych. Uiszcza się ją na rachunek właściwego urzędu wojewódzkiego.

Wojewódzka komisja działa w ramach protokołowanych posiedzeń. W posiedzeniach, z wyjątkiem tego, w trakcie którego odbywa się narada i głosowanie nad orzeczeniem, może uczestniczyć podmiot składający wniosek oraz przedstawiciel:

1. kierownika podmiotu leczniczego prowadzącego szpital, z którego działalnością wiąże się wniosek o ustalenie zdarzenia medycznego,

2. ubezpieczyciela, z którym podmiot leczniczy prowadzący szpital zawarł umowę ubezpieczenia.

Przedstawicielem, wobec braku innego uregulowania, może być zarówno profesjonalny pełnomocnik jak i inne osoby reprezentujące podmiot, na przykład pracownik szpitala.

Kolejną procedurą pierwszego etapu postępowania przed wojewódzką komisją do spraw orzekania o zdarzeniach medycznych jest postępowanie dowodowe. $\mathrm{W}$ jego trakcie rozpatrywane są dowody przedstawione przez podmiot składający wniosek, kierownika podmiotu leczniczego prowadzącego szpital i ubezpieczyciela.

6 J. Sadowska, Postępowanie dowodowe przed wojewódzka komisja do spraw orzekania o zdarzeniach medycznych, „Kwartalnik Prawo-Społeczeństwo-Ekonomia” 2016, nr 3, s. 44-45. 
W związku z tym komisja może wzywać do złożenia wyjaśnień wnioskodawcę, kierownika podmiotu leczniczego prowadzącego szpital, z którego działalnością wiąże się wniosek, osoby wykonujące zawód medyczny w podmiocie leczniczym prowadzącym szpital oraz inne osoby, które były w nim zatrudnione lub w inny sposób z nim związane. W zakresie prowadzonego postępowania wojewódzka komisja może żądać dokumentacji gromadzonej przez podmiot leczniczy prowadzący szpital, w tym dokumentacji medycznej, przeprowadzać postępowanie wyjaśniające w podmiocie leczniczym prowadzącym szpital, dokonywać wizytacji pomieszczeń oraz rewizji urządzeń szpitala.

Wojewódzka komisja, po naradzie, wydaje orzeczenie o zdarzeniu medycznym albo jego niezaistnieniu wraz z uzasadnieniem, które doręcza się podmiotowi składającemu wniosek, kierownikowi podmiotu leczniczego prowadzącego szpital oraz ubezpieczycielowi.

Ustawodawca nie przewidział możliwości odwołania od orzeczeń wojewódzkiej komisji do wyższej instancji. Pacjent ma jednak prawo do złożenia wniosku o ponowne rozpatrzenie sprawy. Zgodnie $\mathrm{z}$ art. $67 \mathrm{j}$ ust. $7 \mathrm{w}$ terminie $14 \mathrm{dni}$ od dnia doręczenia orzeczenia wraz z uzasadnieniem, podmiotowi składającemu wniosek, kierownikowi podmiotu leczniczego prowadzącego szpital oraz ubezpieczycielowi przysługuje prawo złożenia do wojewódzkiej komisji umotywowanego wniosku o ponowne rozpatrzenie sprawy.

\section{ROLA KOMISJI W ZAKRESIE PRZETWARZANIA DANYCH OSOBOWYCH}

Komisje jako organy rozstrzygające, są powołane w celu orzekania o zdarzeniu medycznym albo jego braku, działają na podstawie własnych kompetencji. W celu wydania orzeczenia o zdarzeniu medycznym, wojewódzkie komisje przetwarzają szereg danych osobowych, zarówno wnioskodawców, jak i innych osób, będących lub nie, uczestnikami postępowania. Są to dane zwykłe — służące choćby do zweryfikowania tożsamości konkretnych osób oraz dane należące do kategorii szczególnych — zwłaszcza dane o stanie zdrowia ${ }^{7}$. Od generalnej zasady wyrażonej

7 Zgodnie z motywem 35 RODO, do danych osobowych dotyczących zdrowia należy zaliczyć wszystkie dane o stanie zdrowia osoby, której dane dotyczą, ujawniające informacje o przeszłym, obecnym lub przyszłym stanie fizycznego lub psychicznego zdrowia osoby, której dane dotycza. Do danych takich należą także informacje o danej osobie fizycznej zbierane podczas jej rejestracji do usług opieki zdrowotnej lub podczas świadczenia jej usług opieki zdrowotnej: numer, symbol lub oznaczenie przypisane danej osobie fizycznej w celu jednoznacznego zidentyfikowania tej osoby fizycznej do celów zdrowotnych. Do tych danych zakwalifikować należy również informacje pochodzące z badań laboratoryjnych lub lekarskich części ciała lub płynów ustrojowych, w tym danych genetycznych i próbek biologicznych oraz wszelkie informacje, na przykład o chorobie, niepełnosprawności, ryzyku choroby, historii medycznej, leczeniu klinicznym lub stanie fizjologicznym lub biomedycznym osoby, której dane dotyczą, niezależnie od ich źródła. Ogólne rozporządzenia 
w art. 9 ust. 1 RODO, zakazującej przetwarzania danych osobowych szczególnych kategorii, czyli na przykład tych dotyczących zdrowia, prawodawca unijny wprowadził w ust. 2 tego przepisu pewne wyjątki. Wśród nich znajduje się dopuszczalność przetwarzania danych o stanie zdrowia jeśli osoba, której dane dotyczą, wyraziła wyraźną zgodę na przetwarzanie tych danych osobowych w jednym lub kilku konkretnych celach, jak również gdy przetwarzanie jest niezbędne do ustalenia, dochodzenia, obrony roszczeń lub w ramach sprawowania wymiaru sprawiedliwości przez sądy. Warto tu przytoczyć także treść motywu 52 RODO, w którym dopuszcza się przetwarzanie danych o stanie zdrowia w postępowaniach toczących się przed organami quasi-sądowymi. Prawodawca unijny przewidział w nim wyjątek od zakazu przetwarzania danych o stanie zdrowia. Są to sytuacje, w których jest to niezbędne do ustalenia, dochodzenia lub obrony roszczeń w postępowaniu sądowym, administracyjnym lub też innym postępowaniu pozasądowym.

Ze względu na temat opracowania ważna jest odpowiedź na pytanie o status komisji wojewódzkiej w ustalaniu zdarzenia medycznego: czy można przypisać jej rolę administratora danych osobowych, czy też współadministratora? Zgodnie $\mathrm{z}$ art. 4 pkt 7 RODO administratorem jest osoba fizyczna lub prawna, organ publiczny, jednostka lub inny podmiot, który samodzielnie lub wspólnie z innymi ustala cele i sposoby przetwarzania danych osobowych. Komisje są instytucjonalnie powiązane i zależne od organu administracji publicznej, jakim jest wojewoda. Przesądza o tym między innymi sposób powoływania jej członków, kwestia finansowania i obsługi przez pracowników urzędu wojewódzkiego ${ }^{5}$. Uwzględniając wszystkie poczynione uwagi, należy skonstatować, że komisja wojewódzka ma ściśle określony przepisami cel działania. Jest nim ustalenie, czy wskazane zdarzenie ma charakter medyczny.

W związku z zadaniami przypisanymi komisji, a głównie jej charakterem, pojawiają się wątpliwości odnoszące się do jednoznacznego określenia statusu komisji w kontekście przetwarzania danych osobowych. W literaturze wyrażono nawet pogląd, że najbardziej optymalnym rozwiązaniem byłoby przyjęcie, iż to wojewoda jest administratorem danych osobowych. Powołani przez niego członkowie komisji powinni zostać przez niego upoważnieni do ich przetwarzania, w związku z prowadzonymi postępowaniami toczącymi się przed komisją, zmierzającymi do ustalenia, czy zdarzenie opisane we wniosku jest zdarzeniem medycznym ${ }^{8}$. Upoważnienie, zgodnie z prezentowaną opinią, powinno obejmować swym zakresem umocowanie do przetwarzania danych osobowych $\mathrm{w}$ celu

Parlamentu Europejskiego i Rady (UE) 2016/679 z dnia 27 kwietnia 2016 roku w sprawie ochrony osób fizycznych w związku z przetwarzaniem danych osobowych i w sprawie swobodnego przepływu takich danych oraz uchylenia dyrektywy 95/46/WE (ogólne rozporządzenie o ochronie danych, Dz.Urz. UE z 2016 r. nr 119/1 ze zm.).

8 A. Klich, RODO w postępowaniu przed wojewódzka komisją do spraw orzekania o zdarzeniach medycznych, [w:] Ochrona danych osobowych w postepowaniach sadowych i przed organami administracji publicznej, red. K. Flaga-Gieruszyńska, J. Gołaczyński, Warszawa 2019, s. 94. 
rozpatrywania wniosków o ustalenie zdarzenia medycznego przez wojewódzkie komisje oraz przeprowadzanie postępowania zmierzającego do ustalenia, czy zdarzenie opisane we wniosku jest zdarzeniem medycznym. Autorzy tego stanowiska odrzucają jednocześnie możliwość przyjęcia, że komisja wojewódzka i wojewoda są współadministratorami danych osobowych, ponieważ takie rozwiązanie mogłoby rodzić problemy dotyczące wskazania administratora, czyli podmiotu, który miałby ustalać cel przetwarzania danych osobowych ${ }^{9}$.

Nie sposób jednak zgodzić się z tym zapatrywaniem. Po pierwsze, o współadministrowaniu decydować powinny faktyczne zadania i role określonych podmiotów, między którymi następują przepływy danych i biorących udział w procesie przetwarzania danych osobowych, nie zaś skala trudności w analizie tych ról. Po drugie, trudno bezkrytycznie przyjąć, że wskazanie przez ustawodawcę celu i charakteru funkcjonowania komisji powoduje, że nie decyduje ona samodzielnie o celach przetwarzania danych osobowych (co, jak się wydaje, sugerują autorzy) i z tego względu nie jest ona administratorem danych. Nie przekonuje także stanowisko, że to wojewoda upoważnia członków komisji do przetwarzania danych w celu merytorycznego rozstrzygnięcia, czyli ustalenia, czy doszło do zdarzenia medycznego. Komisja w realizacji tego celu podejmuje autonomicznie decyzje o konieczności i zakresie działań, które zmierzać mają do ustalenia zdarzenia medycznego. W związku z realizacją tego obowiązku podejmuje określone w przepisach działania, które obejmują także przetwarzanie danych osobowych. Treść wniosku inicjującego wszczęcie postępowania jest określona przez przepisy ustawy o prawach pacjenta. Do wniosku dołączana jest dokumentacja medyczna oraz dowody na potwierdzenie zarzutów wnioskodawcy. Informacje te są analizowanie przez skład orzekający komisji i na tej podstawie komisja podejmuje decyzję o prowadzeniu postępowania. W jego toku komisja może również podejmować kolejne działania służące weryfikacji lub uzupełnieniu informacji wskazanych we wniosku. W tym celu może wzywać określone osoby do złożenia wyjaśnień oraz żądać dokumentacji prowadzonej przez podmiot leczniczy prowadzący szpital, w tym dokumentacji medycznej ${ }^{10}$, przeprowadzać postępowanie wyjaśniające $\mathrm{w}$ podmiocie leczniczym prowadzącym szpital, dokonywać wizytacji pomieszczeń i urządzeń szpitala. Samodzielnie decyduje więc o tym, jakie informacje, $w$ tym dane osobowe, przetwarza na potrzeby konkretnego etapu postepowania i orzeczenia.

Komisja, o czym była już mowa, przetwarza dane osobowe nie tylko uczestników postępowania, lecz także innych osób — wskazanych w trakcie postępo-

9 Ibidem.

10 M. Śliwka, Prawo pacjenta do dokumentacji medycznej a postępowanie przed wojewódzkimi komisjami do spraw orzekania o zdarzeniach medycznych, [w:] Kompensacja szkód wyniktych ze zdarzeń medycznych. Problematyka cywilnoprawna i ubezpieczeniowa, red. E. Kowalewski, Toruń 2011, s. 275; idem, Wybrane czynniki determinujące działalność wojewódzkich komisji do spraw orzekania o zdarzeniach medycznych, „Prawo i Medycyna” 2012, nr 3/4, s. 19. 
wania wyjaśniającego przez strony czy też w dowodach przedstawianych przez wnioskodawców oraz zobowiązanych do złożenia wyjaśnień przez skład orzekający komisji ,z urzędu”. Dane te pozyskiwane są również w trakcie wizytacji szpitala. Jeżeli stwierdzenie okoliczności mających istotne znaczenie dla wydania orzeczenia wymaga wiadomości specjalnych, wojewódzka komisja zasięga opinii lekarza albo konsultanta wojewódzkiego w danej dziedzinie medycyny, farmacji lub innej dziedzinie mającej zastosowanie w ochronie zdrowia. Lekarz wezwany do złożenia wyjaśnień ma status świadka. W postępowaniu przed wojewódzką komisją jest on zwolniony z zachowania tajemnicy lekarskiej. Zgodnie bowiem $\mathrm{z}$ art. 14 u.p.p. osoby wykonujące zawód medyczny są obowiązane zachować w tajemnicy informacje związane z pacjentem, w szczególności z jego stanem zdrowia. Od zasady tej wyjątek przewiduje art. 14 ust. 2a u.p.p., zgodnie z którym zasady zachowania tajemnicy lekarskiej nie stosuje się do postępowania przed wojewódzką komisją do spraw orzekania o zdarzeniach medycznych, o której mowa w art. 67 e ust. 1 u.p.p. W związku z tym lekarz ma nie tylko prawo, lecz także obowiązek przekazać w toku postępowania dowodowego informacje o pacjencie, nie naruszając tym samym tajemnicy lekarskiej ${ }^{11}$.

Do zadań komisji należy zatem przede wszystkim merytoryczne rozpatrywanie wniosków określonych osób fizycznych o ustalenie zdarzenia medycznego i prowadzenie postepowania. Co za tym idzie także przetwarzanie wszystkich danych osobowych, w zakresie niezbędnym do rzetelnego i wnikliwego rozpatrzenia sprawy.

\section{ZADANIA WOJEWODY W ZAKRESIE PRZETWARZANIA DANYCH OSOBOWYCH PRZETWARZANYCH W POSTEPOWANIACH PRZED WOJEWÓDZKĄ KOMISJĄ DO SPRAW ZDARZEŃ MEDYCZNYCH}

W toku postępowania o ustalenie zdarzenia medycznego ważną rolę odgrywa także wojewoda. Przypisane mu w tym obszarze przez ustawodawcę zadania wymagają przetwarzania danych osobowych. Bez wątpienia wojewoda przetwarza dane osobowe członków komisji, ponieważ do jego zadań należy obowiązek powołania do jej składu czternastu osób, zgłoszonych przez wskazane w przepisach ustawy podmioty. Wyznacza on, spośród członków wojewódzkiej komisji, osobę, która przewodniczy pierwszemu posiedzeniu, do czasu wyboru przewodniczącego, oraz termin pierwszego zebrania. Jest także organem uprawnionym do odwoływania członków komisji, w razie ziszczenia się którejś z przesłanek wskazanych w art. 67e ust. 9 u.p.p. Oznacza to, że wojewoda przetwarza dane zwykłe i wrażliwe (na przykład odwołanie członka komisji w razie choroby trwale uniemożliwiającej wykonywanie powierzonych zadań), informacje o wyrokach

11 M. Serwach, Lekarz jako świadek w postępowaniu przed Wojewódzką Komisją ds. Orzekania o Zdarzeniach Medycznych, „Medycyna Praktyczna” 2013, nr 5, s. 124. 
i skazaniach (art. 64e ust. 4 u.p.p.). Nie jest natomiast do końca jasna rola wojewody w kontekście przesłanki umożliwiającej odwołanie członka komisji, w razie uchylania się od wykonywania obowiązków albo ich nieprawidłowego wykonywania. Przy braku wskazania podmiotu nadzorującego merytorycznie pracę członków komisji i konieczności odwołania jednego z nich, gdy nie realizuje on zadań albo wykonuje je nieprawidłowo, można przyjąć, że wojewoda musi przynajmniej uczestniczyć w ocenie jakości pracy wskazanej osoby.

Zgodnie z art. 67h ust. 1 i 3 u.p.p. członkom składu orzekającego przysługuje wynagrodzenie w wysokości nieprzekraczającej 430 zł za udział w posiedzeniu, zwrot kosztów przejazdu w wysokości i na warunkach określonych w przepisach wydanych na podstawie art. $77^{5} \S 2$ k.p. ${ }^{12}$ oraz zwolnienie od pracy w dniu posiedzenia komisji, bez zachowania prawa do wynagrodzenia. Wysokość wynagrodzenia za udział w posiedzeniu komisji, ustala właściwy wojewoda ${ }^{13}$. Prawo do wynagrodzenia przysługuje tylko w razie powołania członka komisji do składu orzekającego.

Mimo wskazanych zadań nie można uznać, że decyduje to o przyznaniu wojewodzie statusu administratora danych przetwarzanych w celu ustalenia zdarzenia medycznego przez wojewódzką komisję do spraw orzekania o zdarzeniu medycznym. Przypisanym wyłącznie wojewodzie celem działania jest jedynie wyłonienie komisji wojewódzkiej, nie zaś merytoryczne rozpatrywanie przez niego sprawy i wydawanie orzeczenia. To zadanie przypisane jest bowiem wyłącznie komisji. Aby mogło być ono wypełnione, wojewoda zobowiązany został do zapewnienia możliwości jej działalności, w tym zapewnienia lokalu, środków na funkcjonowanie oraz obsługę administracyjną i biurową.

Nie ulega jednak wątpliwości, że wojewódzkie komisje do spraw orzekania o zdarzeniach medycznych oraz wojewodowie przetwarzają dane osobowe osób, które są stronami postępowań prowadzonych przez komisje. Każdy z tych podmiotów uczestniczy w procesie przetwarzania danych osobowych w innym zakresie.

12 Ustawa z dnia 26 czerwca 1974 roku, tekst jedn. Dz.U. z 2020 r. poz. 1320.

13 Zob. zarządzenie Wojewody Małopolskiego z dnia 10 marca 2014 roku w sprawie ustalenia wysokości wynagrodzenia członków Wojewódzkiej Komisji do Spraw Orzekania o Zdarzeniach Medycznych w Krakowie (nr poz. Re. 47/14), zgodnie z którym członkowi składu orzekającego Wojewódzkiej Komisji do Spraw Orzekania o Zdarzeniach Medycznych w Krakowie przysługuje wynagrodzenie za udział w posiedzeniu. Wysokość wynagrodzenia ustala się w kwocie:

a) 250 zł brutto za pierwsze posiedzenie, na którym oprócz czynności formalnych wyłącznie następuje ustalenie w zakresie dopuszczalności wniosku o ustalenie zdarzenia medycznego i jego kompletności formalnej,

b) 430 zł brutto za pierwsze, drugie, trzecie posiedzenie, na którym następuje merytoryczne rozpatrzenie wniosku o ustalenie zdarzenia medycznego,

c) 250 zł brutto za każde kolejne posiedzenie, na którym następuje merytoryczne rozpatrzenie wniosku o ustalenie zdarzenia medycznego, przy czym w każdym przypadku, gdy jest to posiedzenie kończące sprawę, wysokość wynagrodzenia ustala się w kwocie 430 zł brutto,

d) $430 \mathrm{zł}$ brutto za posiedzenie w celu rozpatrzenia wniosku o ponowne rozpatrzenie sprawy oraz skargi o stwierdzenie niezgodności z prawem orzeczenia wojewódzkiej komisji do spraw orzekania o zdarzeniach medycznych. 
Wojewoda uczestniczy w procesie przetwarzania danych osobowych wnioskodawców przede wszystkim w związku z obowiązkiem zapewnienia obsługi kadrowej (komisje są obsługiwane przez pracowników określonego urzędu wojewódzkiego). W związku z tym to wojewoda powinien upoważnić swoich pracowników do wglądu do akt prowadzonych przez wojewódzkie komisje postępowań, w celu zapewnienia możliwości pracy komisji (prowadzenie rejestru wniosków wpływających do komisji, sporządzanie wykazu posiedzeń, przygotowywanie list obecności, przygotowywanie akt spraw, przechowywanie akt spraw w sposób zapewniający ich bezpieczeństwo, udzielanie dostępu do akt uprawnionym podmiotom, informowanie uczestników postępowania o zmianie terminu posiedzenia komisji.

Celem przetwarzania przez wojewodę danych osobowych jest także przechowywanie dokumentacji zakończonych spraw związanych z toczącym się postępowaniem przed wojewódzką komisją. Dane te przetwarzane są w celu ustalenia, czy zdarzenie, którego następstwem była szkoda majątkowa lub niemajątkowa, jest zdarzeniem medycznym, oraz do archiwizacji akt. Zgodnie z art. 67n u.p.p., oświadczenia o braku konfliktu interesów, protokoły oraz orzeczenia wraz z uzasadnieniem są przechowywane przez właściwego wojewodę przez okres dziesięciu lat. Nie dotyczy to dokumentacji medycznej zgromadzonej w postępowaniu, która po jego zakończeniu, jest zwracana podmiotowi składającemu wniosek, na jego żądanie, albo niszczona w sposób uniemożliwiający identyfikację pacjenta, którego dotyczyła. Wojewoda ma prawo przetwarzania dokumentacji w zakresie koniecznym do realizacji określonego w tym przepisie zadania. Wojewoda decyduje o zniszczeniu dokumentacji w sytuacji umorzenia postępowania $\mathrm{z}$ powodu śmierci podmiotu składającego wniosek.

\section{UWAGI KOŃCOWE}

Przeprowadzona analiza pozwala na przyjęcie, że komisja i wojewoda, realizując swoje uprawnienia przysługujące im na podstawie przepisów, mogą być uznani za współadministratorów danych osobowych przetwarzanych na potrzeby wydania orzeczenia o wystapieniu lub nie, zdarzenia medycznego. Powinni więc dokonać wspólnych uzgodnień, w ramach których zostaną określone kwestie nieuregulowane wprost $\mathrm{w}$ przepisach prawa. Wyszczególnić tu można kwestię realizacji określonych obowiązków informacyjnych wobec osób, których dane są przetwarzane, odpowiednie zabezpieczenie danych osobowych wnioskodawców czy też procedurę zgłaszania naruszeń ${ }^{14}$. Dodać należy, że bez względu na uzgodnienia pomiędzy wojewódzką komisją a wojewodą, osoba, której dane dotyczą,

14 Stanowisko takie prezentuje także Prezes UODO: ,Wojewodę oraz wojewódzką komisję do spraw orzekania o zdarzeniach medycznych można uznać za współadministratorów (art. 26 RODO), „Newsletter UODO”, maj 2019, s. 2, https://uodo.gov.pl/p/archiwum-newslettera-dla-iod. 
może wykonywać przysługujące jej prawa wynikające z RODO wobec każdego ze współadministratorów, a więc zarówno w stosunku do komisji, jak i wojewody.

\section{PROVINCIAL COMMISSION FOR ADJUDICATION OF MEDICAL EVENTS VS. GOVERNOR - ROLES AND RESPONSIBILITIES IN PERSONAL DATA PROCESSING}

\section{Summary}

The article discusses the problem of the relationship between the commission for the adjudication of the medical event and the provincial governor in terms of establishment medical event with regard to data processing.

The issue is important from the point of view of determining the tasks, roles and responsibilities of these entities for the processing of personal data.

It is important from a practical point of view to indicate whether there is a relationship between these authorities of separate administrators or co-administration of personal data.

Keywords: voivodship commission for adjudication of a medical event, voivode, personal data, medical data, personal data processing, joint controller

\section{BIBLIOGRAFIA}

Bagińska E., Działalność wojewódzkich komisji do spraw orzekania o zdarzeniach medycznych a wykonywanie władzy publicznej, [w:] Kompensacja szkód wyniktych ze zdarzeń medycznych. Problematyka cywilnoprawna i ubezpieczeniowa, red. E. Kowalewski, Toruń 2011.

Bagińska E., Krupa-Lipińska K., Zdarzenie medyczne a problem przyczynowości, [w:] Kompensacja szkód wyniklych ze zdarzeń medycznych. Problematyka cywilnoprawna i ubezpieczeniowa, red. E. Kowalewski, Torun 2011.

Drozdowska D., O przedmiocie i charakterze prawnym spraw rozstrzyganych przez Wojewódzkie Komisje do Spraw Orzekania o Zdarzeniach Medycznych, „Forum Prawnicze” 2019, nr 5.

Jarocha A., Postępowanie przed wojewódzka komisją do spraw orzekania o zdarzeniach medycznych, „Studia Prawa Publicznego” 2013, nr 1.

Karkowska D., Ustawa o prawach pacjenta i Rzeczniku Praw Pacjenta. Komentarz, Warszawa 2016.

Klich A., RODO w postępowaniu przed wojewódzka komisją do spraw orzekania o zdarzeniach medycznych, [w:] Ochrona danych osobowych w postępowaniach sadowych i przed organami administracji publicznej, red. K. Flaga-Gieruszyńska, J. Gołaczyński, Warszawa 2019.

Paszkowska M., Rozstrzyganie roszczeń pacjenta $w$ trybie administracyjnym, „Przegląd Prawa Publicznego" 2013, nr 7-8.

Sadowska J., Postępowanie dowodowe przed wojewódzka komisją do spraw orzekania o zdarzeniach medycznych, „Kwartalnik Prawo-Społeczeństwo-Ekonomia” 2016, nr 3.

Serwach M., Lekarz jako świadek w postępowaniu przed Wojewódzka Komisją ds. Orzekania o Zdarzeniach Medycznych, „Medycyna Praktyczna” 2013, nr 5.

Śliwka M., Prawo pacjenta do dokumentacji medycznej a postępowanie przed wojewódzkimi komisjami do spraw orzekania o zdarzeniach medycznych, [w:] Kompensacja szkód wyniktych ze zdarzeń medycznych. Problematyka cywilnoprawna i ubezpieczeniowa, red. E. Kowalewski, Torun 2011. 
Śliwka M., Wybrane czynniki determinujące działalność wojewódzkich komisji do spraw orzekania o zdarzeniach medycznych, „Prawo i Medycyna” 2012, nr 3/4.

Wojewodę oraz wojewódzka komisję do spraw orzekania o zdarzeniach medycznych można uznać za współadministratorów (art. 26 RODO), „Newsletter UODO”, maj 2019, https://uodo.gov. $\mathrm{pl} / \mathrm{p} /$ archiwum-newslettera-dla-iod.

\section{AKTY PRAWNE}

Ogólne rozporządzenia Parlamentu Europejskiego i Rady (UE) 2016/679 z dnia 27 kwietnia 2016 roku w sprawie ochrony osób fizycznych w związku z przetwarzaniem danych osobowych i w sprawie swobodnego przepływu takich danych oraz uchylenia dyrektywy 95/46/WE (ogólne rozporządzenie o ochronie danych, Dz.Urz. UE z 2016 r. nr 119/1 ze zm.).

Ustawa z dnia 26 czerwca 1974 roku, tekst jedn. Dz.U. z 2020 r. poz. 1320.

Ustawa z dnia 6 listopada 2008 roku o prawach pacjenta i Rzeczniku Praw Pacjenta, tekst jedn. Dz.U. 2020, poz. 849.

Ustawa z dnia 15 kwietnia 2011 roku o działalności leczniczej, tekst jedn. Dz.U. z 2020 r. poz. 295. 